\title{
Panorama comparativo entre o Código Civil de Québec e o novo Código Civil Brasileiro: duas experiências recentes de recodificação*
}

\author{
Marcos de Campos Ludwig \\ Mestrando em Direito Privado pela UFRGS \\ Pesquisador-bolsista da Fundação CAPES
}

SUMÁRIO:

INTRODUÇÃO

PARTE I. Aspectos estruturais da codificação

A) Características. B) Técnica legislativa. C) Sistematização da matéria.

PARTE II. Principais soluções jurídicas adotadas

A) Personalidade. B) Família e sucessões. C) Bens. D) Obrigaçōes.

CONCLUSÃO

OBRAS CONSULTADAS

"Na exposição das regras que constituem um Código, todo povo, escolhendo-as, como se escolhe a si mesmo - as suas qualidades e os seus defeitos refletem-se na obra literária e

no pensamento do código."

Pontes de Miranda**

\section{Introdução}

Escreveu Pontes de Miranda sobre 0 direito brasileiro, que este "não pode ser estudado desde as sementes; nasceu do galho de planta, que o colonizador português (...) trouxe e enxertou no novo continente" ${ }^{1}$. Circunstân-

Este artigo consiste na monografia escrita para a disciplina de Direito Comparado, ministrada pelo professor Me. Sérgio José Porto no curso de mestrado do Programa de Pós-Graduação em Direito da UFRGS, durante o primeiro semestre de 2000. As referências ao novo Codigo Civil brasileiro, então ainda em tramitação legislativa

Fontes e evolução do direito civil brasileiro, 2. ed., Rio de Janeiro, Forense, 1981, p. 8.

${ }^{1}$ PONTES DE MIRANDA, op. cit., p. 27. 
cia similar experimentou o Canadá e, em especial, o direito civil na província de Québec, com a influência originária do ordenamento jurídico francês.

Nos seus primórdios, o terreno canadense era ocupado por ameríndios ao sul e inuit ou esquimós, ao norte, tendo sido descoberto pelos europeus no ano de 1497 - ou seja, no mesmo momento histórico em que se deu a chegada dos portugueses ao Brasil. Desenhandose uma brevíssima linha cronológica, verificase que, em 1534, Jacques Cartier ocupa, em nome do Rei da França, o território que hoje equivale à província de Québec; em 1608 Samuel de Champlain instala-se às margens do rio SaintLaurent, em um local chamado pelos nativos de Kébec, que vem a tornar-se a cidade de Québec em 1642 é fundada a Ville-Marie, que depois receberá o nome de Montréal. No período que vai do ano de 1660 a 1713, ocorre uma expansão acelerada da chamada Nova França, com o surgimento de diversas colônias francófonas.

Em 1759 advém a derrota da França nas guerras franco-inglesas, o que acarreta a assinatura do Tratado de Paris (1763), culminando na entrega do Canadá inteiro, já com esse nome, à Coroa britânica. É um período de ruptura na supremacia francesa, que se estende até $o$ ano de 1791, quando enfim é promulgado o Ato Constitucional que estabelece o regime parlamentar e reconhece aos canadenses franceses um foro nacional. Data dessa época a divisão do país em duas grandes regiões: o Haut-

Canada (de domínio inglês, tendo Ontario por capital) e o Bas-Canada (de domínio francês, centralizado na cidade de Québec). Em 1837, cabe acrescentar, estoura uma rebelião dos patriotas do Bas-Canada, insatisfeitos com a situação vigente, mas o movimento não logra maior êxito político.

É com esse pano de fundo que se aprova, no ano de 1865, o Code Civil du BasCanada, composto de 2.600 artigos distribuídos em quatro livros, sob forte inspiração do modelo napoleônico de 1804 e intimamente ligado às ambições nacionalistas de Québec ${ }^{2}$. Apesar de modificações legislativas posteriores, bem como profícuo desenvolvimento jurisprudencial, esse documento codificatório vigorou na província francófona desde 1866 até o dia 31 de dezembro de $1993^{3}$

Logo após sua entrada em vigência, no ano de 1867, é assinado o Acte de l'Amérique $d u$ Nord Britannique, que restou consagrado como Lei Constitucional canadense ${ }^{4}$. Estabeleceu-se então uma confederação composta por quatro províncias: de um lado, Québec (bilingüe); de outro, Ontario, NouveauBrunswick e Nouvelle-Écosse (de língua inglesa)

Permitindo-se um salto histórico de um século, chega-se à década de 1960 e à chamada révolution tranquille, movimento em prol da independência da província de Québec. Tal é o contexto político em que se situa o início dos trabalhos de reforma do Code Civil du Bas-

2 GUY, Codifications et consolidations législatives à l'étranger, Revue du Droit Public et de la Science Politique en France et à l'étranger, Paris, Librairie Générale de Droit e de Jurisprudence, mai.jun. 1998, n. 3, p. 869. ${ }^{3}$ Foi, inclusive, a 18 de dezembro de 1992, aprovada uma lei para regular essa transição (Loi sur l'application de la réforme du Code Civil), tendo entrado em vigor justamente no mesmo dia 1. de janeiro de 1994. A respeito das questões surgidas em matéria de direito transitório, v. JOBIN, Le droit transitoire et le code civil du Québec, Revue Trimestrielle de Droit Civil, Paris, Dalloz-Sirey, jan.-mar. 1995, n. 1, pp. 207-212.

4 Mesmo hoje, face ao advento da Lei Constitucional de 1982, entende-se que a Constituição canadense é composta não apenas por este documento como também por alguns dispositivos ainda vigentes do Acte de l'Amérique du Nord Britannique de 1867 (e.g., os arts. 91 a 93, relativos à repartição de competências - v. infra, nota 48

Revista da Faculdade de Direito da UFRGS, v. 21, Março/2002
Canada, impregnado pelas discussões em torno da crise do federalismo canadense, situação que se alonga pelas décadas seguintes ${ }^{5}$. Afinal, em 1980, realiza-se o referendum popular que rejeita o projeto de "soberania-associação" de Québec com o governo federal do Canadá

O que parecia significar um sinal de harmonia federalista no país, contudo, é ameaçado pela promulgação da nova Lei Constitucional, em 1982, após um acordo preliminar entre o governo federal e as províncias anglófonas. Com efeito, a ausência de qualquer consulta à província de Québec, quando da realização da conferência constitucional de Ottawa, em novembro de 1981 , revolta a comunidade jurídica québécoise, que classifica tal ato como uma "traição" por parte do primeiro-ministro canadense, que tacitamente assumira um compromisso com o povo de Québec em face do resultado do referendum de $1980^{6}$

De qualquer modo, a Lei Constituciona de 1982 foi acatada pela província de Québec, em nova solução de compromisso com a integridade da federação canadense, e encontra-se atualmente em pleno vigor. Em seu "Anexo B",

o documento traz a Charte canadienne des droits et libertés, cujos efeitos se irradiam sobre todo o ordenamento jurídico: seguindo a tendência internacional, as normas ali compreendidas proporcionam uma verdadeira perspectiva constitucional do direito civil? .

No entanto, o tema do presente trabalho não é o direito civil québécois, mas tãosomente o novo Código Civil de Québec, aprovado a 18 de dezembro de 1991, depois de longos debates legislativos, e vigente na província francófona desde 1 . de janeiro de 1994 . Trata-se de um documento legislativo, pois, e como tal será abordado.

Cabe ressaltar, por derradeiro, o fato de ser uma codificação bastante recente, posterior à "onda de constitucionalismo" que pode ser identificada internacionalmente a partir da promulgação das Constituições portuguesa (1976) e espanhola (1978), englobando tanto a já referida Lei Constitucional canadense (1982) quanto a própria Constituição brasileira $(1988)^{8}$. Na maioria dos países, ao contrário da situação québécoise, permanece em vigor um Código Civil "velho" em face de uma Constituição

${ }^{5}$ Sobre o problema do federalismo no Canadá, com ênfase na situação sui generis da província de Québec, v. BRACHET, La crise du fédéralisme canadien et le problème québécois, Revue du Droit Public et de la Science Politique en France et à l'étranger, Paris, Librairie Générale de Droit e de Jurisprudence, mar-abr. 1972, n. 2, pp. 303-324.

${ }^{6}$ A respeito da forte controvérsia que acompanhou a promulgação da Lei Constitucional de 1982, dita pelos anglófonos Canada Bill, v. por todos PHILIP, Le Québec et le "repatriement" de la Constitucion canadienne anglófonos Canada Bill, v. por todos PHILIP, Le Québec et le "repatriement" de la Constitución canadienne,
Revue du Droit Public et de la Science Politique en France et à l'étranger, Paris, Librairie Générale de Droit Revue du Droit Public et de la Science Politique en France

A importante questão do chamado "direito civil constitucional" vem sendo versada e criticada por diversos doutrinadores, tanto estrangeiros quanto nacionais, mas foge ao âmbito do presente trabalho. A esse respeito, e.g., v. RAISER, La Costituzione e il diritto privato, in: Il compito del diritto privato, trad. por Marta Graziadei, Milão, Giuffrè, 1990, pp. 169-191; PRATA, A tutela constitucional da autonomia privada, Coimbra, Almedina, 1982, p. 56 e ss.; PERLINGIERI, Perfis do direito civil, trad. por Maria Cristina De Cicco, 3. ed., Rio de Janeiro, Renovar, 1997, passim.

${ }^{8}$ Cabe sinalar que não se encontram dentro da mencionada "onda", à guisa de exemplo, os ordenamentos jurídicos da Itália, da Alemanha e da França, países que mantiveram suas Constituiçōes da época do pós-Guerra (promulgadas em 1947, 1949 e 1958, respectivamente); já nos Estados Unidos, como é notório, permanece em vigor a Constituição de 1787, composta apenas de sete artigos, com o acréscimo das respectivas amendments. Sobre os pricis outros país, v. MIRANDA, Manual direito constitucional, 4. ed., Coimbra, Coimbra, 1990, t. I, p. 99 e ss.

Revista da Faculdade de Direito da UFRGS, v. 21, Março/2002 
"nova"; ganha interesse extra, portanto, a experiência canadense de recodificação, devido a essa peculiaridade ${ }^{9}$

Em suma, tendo em mente tratar-se aqui de um documento codificatório, em um primeiro momento serão contemplados os aspectos estruturais do novo Código Civil do Québec, cuja importância não pode ser subestimada, para que depois se possa estudar sua substância - i.e., as principais soluções jurídicas nele incorporadas. Nesse sentido, impera que não se perca de vista a lição de Clóvis do Couto e Silva, antes de desenhar um panorama do direito civil brasileiro, quando alertou que "de outro modo, terse-á a justaposição de soluções jurídicas, sem que se defina sua estrutura intima" ${ }^{10}$.

Tal preocupação embasará o desenvolvimento deste trabalho.

\section{PARTE I}

\section{Aspectos Estruturais Da}

\section{Codificação}

\section{A) Características}

O que primeiro se deve sinalar, ao debruçar-se sobre o Código Civil de Québec, é o fato de tratar-se de uma codificação oriunda de um consenso, obtido após longo período de gestação.
Uma análise histórica da reforma ocorrida no ordenamento jurídico civilístico de Québec, de fato, conduz o estudioso até, pelo menos, a década de 1960 , conforme já se indicou. É nessa época, justamente, que se verifica a necessidade premente de atualizar as disposições do Code Civil du Bas-Canada, diploma aprovado em 1865 e vigente desde 1866. São elucidativas, nesse aspecto, as palavras de Pierre-Gabriel Jobin ${ }^{11}$ :

"Le code civil du Bas-Canada a bien vieilli depuis son adoption en 1865: il fallait le mettre à jour sur les plans social et économique, et le temps était venu d'ouvrir le droit québécois à certaines institutions et techniques juridiques modernes; l'occasion était propice pour refaire une toilette à la terminologie du code et à sa structure, en continuité avec le droit antérieur tel que vécu par la jurisprudence et le doctrine."

É oportuno apontar que, no caso do Código Civil brasileiro, em vigor desde o dia 1 . de janeiro de 1917, igualmente se percebeu a conveniência de uma toilette legislativa, que culminou na elaboração do Projeto de lei recém sancionado $^{12}$. Assim, também o novo Código Civil (Lei 10.406, de 10 de janeiro de 2002) experimentou um longo período de gestação, uma vez que a comissão responsável pela redação do respectivo Anteprojeto foi constituída em maio de 1969, e a tramitação do texto no Congresso Nacional teve início em 1975.

Quanto à reforma do Code Civil du BasCanada, portanto, os debates jurídicos culmi-

$9 \mathrm{~V}$. infra, nota 15

${ }^{10}$ COUTO E SILVA, O direito civil brasileiro em perspectiva histórica e visão de futuro, in: $O$ direito privado brasileiro na visão de Clóvis do Couto e Silva, org. por Vera Maria Jacob de Fradera, Porto Alegre, Livraria do Advogado, 1997, p. 11 (grifamos).

11 JOBIN, Le nouveau code civil, Revue Trimestrielle de Droit Civil, Paris, Dalloz-Sirey, out.-dez. 1993, n. 4, p. 911 (grifamos).

${ }^{12}$ A respeito da tramitação legislativa do Projeto do novo Código Civil brasileiro, v. por todos REALE, $O$ Projeto do novo Código Civil, 2. ed, São Paulo, Saraiva, 1999, passim.

Revista da Faculdade de Direito da UFRGS, v. 21, Março/2002

naram, mormente na década de 1980, em vários conjuntos de modificações dispersas, seja em matéria de direito de família, pessoas, sucessões ou bens ${ }^{13}$. $\mathrm{O}$ resultado foi a manutenção de um código civil de caráter antigo, ultrapassado, mas com inúmeros remendos legislativos a concederem-lhe certa atualidade. A partir daí, surgiu a questão da pertinência da recodificação do direito civil de Québec, abrindo-se espaço uma ampla discussão na comunidade jurídica loca ${ }^{14}$. Finalmente, aquelas reformas setorizadas foram acolhidas e sistematizadas no novo Código Civil da província de Québec, aprovado no dia 18 de dezembro de 1991 e vigente desde o dia 1. de janeiro de 1994.

Essa circunstância, pode-se afirmar, deu ao Código Civil de Québec uma naturez dúplice: é um diploma legislativo que, ao mesmo tempo em que recepciona algumas regras do antigo Code Civil du Bas-Canada, apre-

${ }^{13}$ Sobre o desenvolvimento das diversas fases desse processo de reforma, em quadro sistemático, v. VACHON Une vue d'ensemble du nouveau code civil du Québec, Le Réseau Juridique du Québec, Internet, 2000, http: /www.avocat.qc.ca/public/iiccqvachon.htm; v. ainda JOBIN, Le nouveau cit., pp. 912-913.

${ }^{14}$ De fato, mais de duzentos memoriais foram apresentados ao Office de révision do código civil, oriundos dos mais diversos segmentos da sociedade de Québec.

${ }^{15}$ Também nesse ponto cabe sinalar a semelhança com o caso do Brasil, onde foi promulgada, a 5 de outubro de 1988 - ou seja, durante o processo de recodificação do direito civil - uma nova Constituição. No entanto, devese reiterar que, na maioria dos países da família jurídica romano-germânica (utiliza-se a terminologia notoriamente adotada por DAVID, Os grandes sistemas do Direito contemporaneo, trad. por Herminio A. Carvalho, Constituiç̃o "nov".

Sobre as peculiaridades da família jurídica da common law, v. DAVID, $O$ direito inglês, trad. por Eduardo Brandão, Sao Paulo, Martins Fontes, 1997, passim. Em visão histórica do rapprochement entre a tradição da de Droit Comparé, Paris, Société de Législation Comparée, jul-set. 1993, n. 3, pp. 559-575. No caso particular do Canad́a essa mescla originou frutos interessantíssimos para os estudios. como exemplo mais significativo a adoc̃̃o, pelo Código Civil de Québec, da cléssica figura do trust, através do instituto da fiducie ( $\mathrm{v}$, infra parte II, C). Tal processo, vale sempre frisar é mútuo, de modo que também as províncias anglófonas, mediante a crescente influência do direito civil québécois, sentiram a necessidade as provincias anglofonas, mediante a crescente influência do direito civil , québecois, sentiram a necessidade de uma adaptação que gerou interessantes reflexos linguísticos, inclusive, conforme expoe DIDIER, La common Droit Comparé, Paris, Société de Législation Comparée, jan.-mar. 1991, n. 1, pp. 7-56.

Cabe sinalar ainda, nesse aspecto, as peculiaridades do método de interpretação e aplicação da lei pelo juiz québécois, que, de certa forma, mescla o pragmatismo do espírito britânico com o rigor cartesiano do espírito francês, como ressalta MAZEN: "En conclusion, si la plupart des institutions judiciaires québécoises sont essentiellement inspirées de la tradition civiliste, on ne saurait nier une influence profonde de la pratique anglaise, principalement dans le déroulement des procès qui emprunte le schéma des instances anglo-américaines. Cette évolution spécifique est certainement l'une des caractéristiques fondamentales de la justice québécoise (...)" (Le juge civil québécois [approche comparative d'un système de droit mixte], Revue Internationale de Droit Comparé, Paris, Société de Législation Comparée, abr.-jun. 1982, n. 2, p. 403).

Revista da Faculdade de Direito da UFRGS, v. 21, Março/2002 


\section{B) Técnica legislativa}

Sabe-se que a técnica legislativa adotada pelos códigos oitocentistas mostra-se, hoje insuficiente para a satisfatória resolução dos problemas que se põem como desafio ao Direito. Com base nessa premissa, verifica-se um denso desenvolvimento doutrinário quanto a alternativas que levem em consideração uma nova concepção de sistema jurídico. Com efeito, impera que se tenha não mais de um código cerrado em si mesmo, com pretensões de completude e autosuficiência, como outrora se esboçou, mas sim uma codificação que reivin dique sua posição central dentro de um sistema aberto, que apresente a mobilidade estrutura necessária para fazer frente às constantes modificações manifestadas no mundo dos fatos, mediante o auxílio da doutrina e a dimensão criadora da jurisprudência ${ }^{17}$.

Face a esse panorama, assume função essencial no código civil a existência de cláusulas gerais, compreendidas por Clóvis do Couto e Silva como "um convite para uma atividade judicial mais criadora, destinada a complementar o corpus juris vigente com novos princípios e normas" 18

À semelhança do que ocorre com o novo Código Civil brasileiro, também o Código Civil de Québec possui alguns énoncés généraux que, na lição de Jobin, constituem aqueles princípios "dont la jurisprudence pourra tirer des applications particulières et grâce auxquels elle pourra faire évoluer le droit sans attendre l'intervention du législateur" ${ }^{19}$. Trata-se daquilo que, em outros países, se designa como cláusulas gerais, significando, em síntese, o recurso técnico-operacional que possibilita o ingresso sistemático no ordenamento jurídico de princípios valorativos e máximas de conduta implícitos, bem como sua constante ressistematização ${ }^{20}$.

O exemplo que mais se destaca aos olhos do estudioso é a consagração do princípio da boa-fé, entendida em sua natureza objetiva - ou seja, nas palavras de Judith MartinsCosta, "a boa-fé como regra de conduta fundada na honestidade, na retidão, na lealdade e, principalmente, na consideração para com os interesses do alter" 21

Tanto o Código Civil de Québec quanto o novo Código Civil brasileiro adotam e concedem importância essencial ao princípio da boafé, como cláusula geral que se irradia sobre todo o ordenamento jurídico privado. Percebe-se logo a similaridade das disposições constantes dos diplomas supracitados ${ }^{22}$ :

\section{.}

\footnotetext{
${ }^{17}$ Nesse sentido, quanto aos trabalhos de elaboração do novo Código Civil brasileiro, ressalta COUTO E SLLVA: "A importância está em dotar a sociedade de uma técnica legislativa e juŕdica que possua unidade valorativa e conceitual "A mesmo tempo em que infunda nas leis especiais essas virtudes, permitindo à doutrina poder integrá-las num sistema mesmo tempo em que infunda nas leis especiais essas virtudes, permitindo à doutrina poder integrá-las num sistema,
entendida, entretanto, essa noção de modo aberto" ( $O$ direito civil cit., p. 30). Em enfoque específico, v. MARTINSentendida, entretanto, essa noção de modo aberto" (O direito civil cit., p. 30). Em enfoque específico, v. MARTiNS-
COSTA, O direito privado como um "sistema em construçăo". As cláusulas gerais no Projeto do Código Civil brasileiro, Revista de Infornaçãa Legislativa, vol. 139, Brasilia, Senado Federal, 1998, pp. 5-22.

${ }_{18}$ COUTTO E SILVA, O direito civil cit., p. 31.

19 JOBIN, Le nouveau cit., p. 913.

${ }^{20}$ MARTINS-COSTA, $O$ direito cit., p. 5 e ss.

${ }^{21}$ MARTINS-COSTA, A boa-fé no direito privado. Sistema e tópica no processo obrigacional, São Paulo, Revista dos Tribunais, 1999 , p. 412

${ }^{22}$ Não obstante a semelhança entre os dispositivos legais transcritos, é significativo o fato de não possuir, o Código Civil de Québec, uma Parte Geral, em harmonia com a tradição francesa. De fato, os arts. 6 e 7 da codificação québecoise estão estatuídos num livro especial, concernente ao estatuto das pessoas, diferentemente do que ocorre com os arts. 113 e 187 do novo Código Civil brasileiro, que apresentam maior amplitude potencial devido à sua localização na Parte Geral do respectivo diploma (v. infra, parte I, C)

Revista da Faculdade de Direito da UFRGS, v. 21, Março/2002
}

\section{CÓDIGOCIVILDEQUÉBEC}

6. Toute personne est tenue d'exercer ses droits civils selon les exigences de la bonne foi.

7. Aucun droit ne peut être exercé en vue de nuire à autrui ou d'une manière excessive déraisonnable, allant ainsi à l'encontre des exigences de la bonne foi.

1.375. La bonne foi doit gouverner la conduite des parties, tant au moment de la naissance de l'obligation qu'à celui de son exécution ou de son extinction.

\section{CÓDIGOCIVIL BRASILEIRO}

Art. 113. Os negócios jurídicos devem ser interpretados conforme a boa-fé e os usos do lugar de sua celebração.

Art. 187. Também comete ato ilícito o titular de um direito que, ao exercê-lo, excede manifestamente os limites impostos pelo seu fim econômico ou social, pela boa-fé ou pelos bons costumes.

Art. 422. Os contraentes são obrigados a guardar, assim na conclusão do contrato, como em sua execução, os princípios de probidade e boa-fé.

Comparando o texto do art. 1.375 do Código Civil de Québec com o do art. 422 do novo Código Civil brasileiro, nota-se que o primeiro dispositivo faz menção expressa também ao momento da extinção da obrigação, enquanto o segundo dispositivo apenas prevê os momentos da celebração e da execução contratual. A aparência de maior amplitude daquele, con- tudo, é afastada pela consideração sistemática, no Código Civil brasileiro, de outros artigos que se prestam à construção de um modelo jurídico de "agir segundo a boa-fé" 23

Outro exemplo de inovação no que tange à técnica legislativa aplicada no Código $\mathrm{Ci}$ vil de Québec, em comparação com o Code Civil du Bas-Canada, é a utilização de corpos de regras de aplicação geral, a fim de prescindir da técnica da incorporação por reenvio, conhecida e posta em prática pelo legislador de $1865^{24}$. São três os casos relevantes:

a) administração de bens de outrem (art. 1.299 e ss.), onde se justifica o emprego da técnica para assentar um fundamento que sirva de suporte ao novo instituto da fiducie $e^{25}$ tendo aplicação em campos tão diversos quanto a tutela e a curatela, o mandato, a liquidação sucessória etc.;

b) restituição das prestações (art. 1.699 e ss.), visando a resolver os problemas oriundos de situações em que uma pessoa é obrigada a devolver a outrem bens recebidos indevidamente, ou por erro, ou em virtude de anulação superveniente retroativa de um determinado ato jurídico;

c) exercício de direitos hipotecários (art. 2.748 e ss.), a fim de dar consistência normativa à igualdade proporcionada pelo novo regime de garantias reais, que se unifica justamente em torno da figura da hypothèque ${ }^{26}$

Por fim, o Código Civil de Québec estabeleceu alguns conceitos novos, como o de actes pour les fins d'une entreprise (art. 1.525), cuja extensão é consideravelmente maior do que a antes compreendida pela noção de actes de

${ }^{23}$ Assim, deve-se levar em conta a aplicação sistemática dos arts. 113, 128 e, especialmente, 187 do novo Código Civil brasileiro, quando for o caso, no constante processo de construção do modelo jurídico supracitado (MARTINS-COSTA, A boa-fé cit., pp. 350 (nota 218) e 518).

${ }^{24}$ JOBIN, Le nouveau cit., p. 915.

${ }^{25} \mathrm{~V}$. infra, parte II, C.

${ }^{26} \mathrm{~V}$. infra, parte II, C. 
commerce, a exemplo do ensinado pela doutrina francesa ${ }^{27}$. É interessante notar, também neste ponto, que o novo Código Civil brasileiro contém inovação semelhante, ao unificar o tratamento das obrigações e reservar um livro para o regramento do direito de empresa ${ }^{28}$.

Outro conceito novo, cuja importância será mais demoradamente analisada adiante, é o de patrimoine d'affectation, que serve de fundamento para o instituto igualmente inovador da fiducie ${ }^{29}$. Com efeito, explica Jobin que o legislador, ao desenvolver tal conceito em título próprio do livro referente aos bens, demonstrou a intenção de "considérer le patrimoine d'affectation comme distinct, dans sa nature, des démembrements du droit de propriété et des modalités du droit de propriété (telle la copropriété), qui font l'objet d'autres titres" ${ }^{30}$.

Deve-se compreender, todavia, que o maior número de definições encontráveis no Código Civil de Québec não faz deste um diploma de caráter excessivamente abstrato, desli- gado do mundo dos fatos. Do mesmo modo que os autores do Anteprojeto brasileiro, o legislador québécois parece ter pautado seu trabalho em um sentido concreto - vale dizer, com Miguel Reale e sob confessa influência de Jhering, à luz do princípio da realizabilidade. Em uma frase, "o Direito é feito para ser realizado" 31 .

\section{C) Sistematização da matéria}

O que primeiro se observa no Código Civil de Québec, ao analisar-se a estrutura adotada para sistematizar a matéria, é a ausência de uma Parte Geral, a exemplo do que já se verificava no Code Civil du Bas-Canada (1865).

Por óbvio, essa circunstância explica-se historicamente, uma vez que a mencionada província representa, de fato, um enclave francês no continente americano. Como tal, seu ordenamento jusprivatístico ainda apresenta inúmeros pontos de contato com a codificação

27 JOBIN, Le nouveau cit., p. 917

${ }^{28}$ Ressalta REALE, porém, que “o direito de empresa não figura, como tal, em nenhuma codificação contemporânea, constituindo, pois, uma inovação original" (op. cit., p. 6). Nesse particular, a idéia fundamental trazida pelo novo Código Civil brasileiro parece ser o emprego da palavra "empresa" com um sentido eminentemente finalístico: segundo REALE, passa-se a considerar empresa aquela "atividade desenvolvida pelos indivíduos ou pelas sociedades a fim de promover a produção e a circulação das riquezas, dos bens e dos serviços" (op. cit., p. 19). Ademais, o Código Civil de Québec, apesar do novo conceito dos actes pour les fins d'une entreprise, não prevê um livro específico para o chamado direito de empresa (v. infra, parte I, C).

${ }^{2}$ A necessidade de um tal fundamento legal, com a previsão de um novo conceito, é manifesta pela notória circunstância de adotar, a província de Québec, a civilística de molde francês. Nas demais províncias canadenses, onde vige o sistema de adotar, a provincia de Québec, a civilística de molde francês. Nas demais províncias canadenses, onde vige o sistema de inglesa e escudados por séculos de tradicão jurisprudencial. Logo, o conceito de patrimoine do d'afectation, em ráltima equálise inglesa e escudados por séculos de tradiçáa jurisprudencial. Logo, o conceito de patrinoine d'affectation, em ültima análise,
viabiliza o implemento do instituto paralelo da fiducie pelo Código Civil de Québec. ${ }^{30}$ JOBIN, Le nouveau cit., p. 917.

${ }^{31}$ REALE, op. cit., p. 10

Revista da Faculdade de Direito da UFRGS, v. 21, Março/2002

que originalmente vigorou no chamado BaixoCanadá: o Code Napoléon (1804) ${ }^{32}$.

A idéia de uma Parte Geral - contendo o que juridicamente estaria "antes dos parênteses”, utilizando a linguagem matemática que está em sua origem teórica ${ }^{33}$ - deve-se fundamentalmente a Leibniz, tendo ocorrido seu posterior desenvolvimento pelos juristas da pandectística alemã, dentre os quais Christian Wolff merece especial destaque, já no século XIX. No fulcro da teoria que lhe dá suporte, está situada a noção de construção sistemáti$c a$ do ordenamento jurídico, enquanto encadeamento lógico-dedutivo ${ }^{34}$.

O Code Napoléon, no entanto, devido tanto à sua inspiração e fundamentos própri$\mathrm{os}^{35}$ quanto à sua antecedência cronológica em

${ }^{32}$ Desse modo, a adoção de uma Parte Geral pelo Code Civil du Bas-Canada, à moda do BGB alemão, seria uma impossibilidade histórica, pois a publicação daquele diploma antecede a codificação germânica em mais de três décadas. Cabe fazer menção, igualmente, que é do ano de 1857 a primeira edição da Consolidação das leis civis, onde, embasado em Leibniz e nos juristas alemães do início do século XIX, nosso Teixeira de Freitas já dividira a materia em una Parte Especial e uma Parte Geral, que serviria "de prolegomenos" à primeira (Introdução, $p$. CXrasileiro de 1916 v emo codigo Civil brasileiro de 1916, v. em especial COUTO E SILVA, Romanismo e germanismo no Codigo Civil brasileiro,

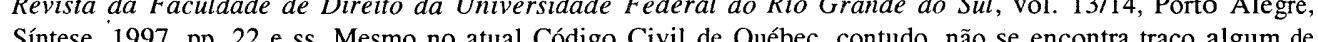
Sintese, $1997, \mathrm{pp} .22$ e ss. Mesmo no athal Cơdigo Civil de Québec, contudo, não se encontra traço algum de nha cia al geral consagradora do princíio da boa-fé tria manifesta inspiraçáa gen ob́a (\$242 do BGB), face ao silêncio (a) jurisprudência de Québec e, finalmente, incorporada ao novo Código Civil, encerrando uma coincidência de lemas similares.

${ }_{3}^{3}$ HATTENHAUER, Conceptos fundamentales del derecho civil, trad. por Gonzalo Hernández, Barcelona, Ariel, 1987, p. 13.

${ }^{34}$ MARTINS-COSTA, O sistema na codificação civil brasileira: de Leibniz a Teixeira de Freitas, Revista da Faculdade de Direito da UFRGS, vol. 17, Porto Alegre, Síntese, 1999, pp. 189-204. Tal, bem se sabe, é a corrente tradicionalmente seguida pelo Código Civil brasileiro, tendo sido mantida e, de certo modo, aperfeiçoada pelo diploma de 2002. Contudo, mesmo na Alemanha, o posicionamento favorável à Parte Geral não é pacífico, conforme atesta WIEACKER, História do direito privado moderno, trad. por A. M. Botelho Hespanha, 2. ed., Lisboa, Calouste Gulbenkian, 1993, pp. 558-561. ${ }^{35}$ Sobre o Code Napoléon e seu contexto histórico, como fruto do pensamento iluminista, v. CAENEGEM, Uma
introdução histórica ao direito privado, trad. por Carlos Eduardo Machado, São Paulo, Martins Fontes, 1995, pp. 1-15. Especificamente quanto à influência teórica de Montesquieu, v. RABELLO, Montesquieu et la codification du droit privé (le Code Napoléon), Revue Internationale de Droit Comparé, Paris, Société de Législation Comparée, jan.-mar. 2000, n. 1, pp. 147-156.

${ }^{36}$ MARTINS-COSTA, A boa-fé cit., pp. 190-191. Nessa concepção de sistema (apenas externo, impossibilitando a sua mobilidade) subjacente ao Code Napoléon, afirma a autora, encontra-se a base estrutural que possibilitou a disseminação do legalismo na jurisprudência francesa, pela Escola da Exegese. 
namento: face às características anteriormente apontadas, quanto à técnica legislativa adotada, pode-se afirmar que o novo diploma québécois possui aquele mesmo espírito oitocentista?

A resposta não pode deixar de ser negativa, e isso com fundamento em pelo menos três características. Em primeiro lugar, consideran do-se a existência de cláusulas gerais e dos já referidos corpos de regras de aplicação geral, percebe-se que há certa dinamicidade interna no Código Civil de Québec, de modo a afastar uma aplicação meramente exegética da lei. Em segundo lugar, os títulos iniciais do Livro I, referente às pessoas (De la jouissance et de l'exercise des droit civils, De certains droits de la personnalité etc.), apresentam claro teor introdutório, proporcionando um certo grau de encadeamento lógico-dedutivo com outros livros e títulos do mesmo documento codificatório. Em terceiro lugar, não pode ser olvidado o fato geopolítico de pertencer, a província do Québec, ao Canadá - ou seja, está situada dentro de um país onde vige um sistema misto, o que lhe acarreta diversas peculiaridades, devido aos elementos de "contágio" com a common law.

Quanto à seqüência de tratamento da matéria, por sua vez, há não poucas diferenças em relação à codificação francesa. Assim, os 3.168 artigos do Código Civil de Québec são divididos em dez livros, dispostos na seguinte ordem: das pessoas (I), da família (II), das sucessões (III), dos bens (IV), das obrigações (V), das prioridades e das hipotecas (VI), da prova (VII), da prescrição (VIII), da publicidade dos direitos (IX) do Direito Internacional Privado (X).

Contudo, por razões de melhor didática e de concisão, apenas as principais soluções jurídicas encontradas no novo diploma québécois serão abordadas no presente trabalho, a seguir, o que justifica o esforço de ressistematização feito para tornar mais adequado o tema ao objetivo panorâmico desta exposição.

\section{PARTE II}

\section{Principais Soluções Jurídicas} Adotadas

\section{A) Personalidade}

Afinado com seu tempo, consagra o Código Civil de Québec, no livro I, atinente às disposições sobre as pessoas, a proteção dos chamados direitos da personalidade. No primeiro título do referido livro (De la jouissance et de l'exercice des droits civils, arts. 1 a 9) já se faz referência a tais direitos, para depois serem aprofundados e individuados em um título próprio (De certains droits de la personnalité, arts. 10 a 49$)$.

O essencial é compreender-se que, mais do que mera decisão terminológica, a previsão de tais direitos indica uma tomada de opção face a distintos desenvolvimentos teóricos, cujas raízes podem ser identificadas em meados do século XIX, na Alemanha ${ }^{37}$. Com efeito, Hattenhauer indica a diferença de fundo existente entre a teoria da pessoa, conforme construída por Savigny e posteriormente ado-

Versamos o tema na monografia $O$ direito ao livre desenvolvimento da personalidade na Alemanha e possibilidades de sua aplicação no direito privado brasileiro, in: MARTINS-COSTA (org.), A reconstrução do direito privado, São Paulo, Revista dos Tribunais, 2002, pp. 265-305. Na doutrina brasileira mais recente, v. ainda CUNHA, Dignidade da pessoa humana: conceito fundamental do direito civil, in: MARTINS-COSTA (org.), $A$ reconstrução do direito privado, São Paulo, Revista dos Tribunais, 2002, pp. 230-264; CORTIANO JR., Alguns apontamentos sobre os chamados direitos da personalidade, in: FACHIN (coord.), Repensando fundamentos do Direito civil brasileiro contemporâneo, Rio de Janeiro, Renovar, 1998, pp. 31-56.

Revista da Faculdade de Direito da UFRGS, v. 21, Março/2002 tada pelo BGB alemão, e a teoria da personalidade, segundo a concepção acatada pelo Código Civil suíço de $1907^{38}$. Enquanto aquele entendimento identifica a personalidade com a mera capacidade jurídica, demonstrando coerência lógica com a teoria savigniana do negóalcance bem mais abrangente.

Etimologicamente já se adquire a noção da diferença ora assinalada: de um lado, sabese que a palavra "pessoa" radica em Roma; o termo "personalidade", por sua vez, é um neologismo de espírito iluminista, criado justamente em fins do século XVIII, que não tem sua origem no Direito, senão na Ética. É fundamental, nesse sentido, a obra de Immanuel Kant em especial, sua Crítica da razão prática -, cuja análise faz Hattenhauer concluir ${ }^{39}$ :

"A pessoa era um conceito jurídico; a personalidade, uma qualidade ética, uma capacitação para a liberdade na qual deveria desenvolver-se o homem. (...) Todo homem, por si mesmo, é já uma personalidade.'

Cabe ressaltar, contudo, que o posterior desenvolvimento da teoria da personalidade veio a afastá-la do espírito individualista burguês, com o qual acabara se impregnando durante o século XIX, para ser retomada em seu cio jurídico, a segunda vertente propõe-lhe um significado ético, mormente a partir dos trabalhos de Otto von Gierke (1895) e Edouard Hölder (1905). Reconhecia-se, aos poucos, um direito geral da personalidade, como a afirmação de "um direito subjetivo que deve ser respeitado por todos" ${ }^{40}$. Tal a idéia que foi oportunamente reforçada e elevada à categoria de valor-fonte do ordenamento jurídico pela Lei Fundamental alemã de $1949^{41}$, bem como pela maioria das Constituições desde então promulgadas, seja de modo expresso ou implícito.

Apresenta-se assim direcionado, pois, o Código Civil de Québec, à semelhança de outros diplomas mais recentes ${ }^{42} \mathrm{e}$, em especial, do novo Código Civil brasileiro ${ }^{43}$. Na elaboração deste, porém, teve-se a preocupação de prever apenas regras consideradas essenciais sobre os direitos da personalidade, possibilitando seu posterior e necessário desenvolvimento pela doutrina e pela jurisprudência, conforme o testemunho de Miguel Reale na Exposição de motivos do Anteprojeto de Código Civil, datada de 16 de janeiro de $1975^{44}$ :

"Todo um capítulo novo foi dedicado aos direitos da personalidade, visando à sua salvaguarda, sob múltiplos aspectos, desde a proteção dispensada ao nome e à imagem até o direito de se dispor do próprio corpo para fins científicos ou altruísticos. Tratando-se de matéria de per si complexa e de significação ética
${ }^{38}$ De fato, o autor do Código Civil suíço, Eugen Huber, era partidário confesso da teoria da personalidade, como leciona HATTENHAUER, op. cit., p. 24.

${ }^{39}$ HATTENHAUER, op. cit., p. 21 (traduzimos).

${ }^{40}$ Otto von Gierke, Deutsches Privatrecht, I, p. 702, apud: HATTENHAUER, op. cit., p. 23 (traduzimos)

${ }^{41}$ Enquanto o art. 1. da Lei Fundamental alemã estabelece a proteção da dignidade da pessoa humana (Menschenwürde), o art. 2. dispõe justamente que "todos têm o direito ao livre desenvolvimento da sua personalidade (freie Entfaltung der Persönlichkeit), desde que não violem os direitos de outrem e não atentem contra a ordem constitucional ou a lei moral". A respeito, v. a nossa monografia cit.

${ }^{42}$ Assim, e.g., o Código Civil português de 1966 (arts. 66. e ss.), ao fazer menção expressa, inclusive, em seu art. 70., à "tutela geral da personalidade" - v. MOTA PINTO, Notas sobre o direito ao livre desenvolvimento da personalidade e os direitos de personalidade no direito português, in: SARLET (org.), A Constituição concretizada. Construindo pontes com o público e o privado, Porto Alegre, Livraria do Advogado, 2000, pp. 61-83. ${ }^{43}$ Arts. 11 a 21.

${ }^{44}$ REALE, op. cit., p. 65 
essencial, foi preferido o enunciado de poucas normas dotadas de rigor e clareza, cujos objetivos permitirão os naturais desenvolvimentos da doutrina e da jurisprudência."

No Código Civil de Québec, por sua vez, predominou um regramento mais minucioso respeito; os fundamentos e diretrizes, porém, não são distintos dos adotados pelo diploma brasileiro, conforme se atesta pelos exemplos a seguir transcritos:

\section{CÓDIGOCIVIL DEQUÉBEC}

1. Tout être humain possède la personnalité juridique; il a la pleine jouissance des droits civils.

10. Toute personne est inviolable et a droit à son intégrité. Sauf dans les cas prévus par la loi, nul ne peut lui porter atteinte sans son consentement libre et éclairé.

\section{CÓDIGOCIVIL BRASILEIRO}

Art. 1. Toda pessoa é capaz de direitos e deveres na ordem civil.

Art. 11. Com exceção dos casos previstos em lei, os direitos da personalidade são intransmissíveis e irrenunciáveis, não podendo o seu exercício sofrer limitação voluntária.

Note-se, todavia, no Código Civil brasileiro, a vinculação imediata da pessoa à capacidade (art. 1.), que denuncia resquícios da noção restritiva da personalidade, conforme entendida pela teoria savigniana da pessoa. Nes-

se particular, portanto, os elaboradores do Anteprojeto preferiram manter a tradição do Código Civil de 1916 e transcrever o texto do art. 2. deste diploma - apenas com a ulterior substituição da palavra "homem", no Senado Federal, pela expressão "ser humano" e então, na Câmara dos Deputados, pela palavra "pessoa". Destarte, revela-se mais feliz a redação do art. 1 do Código Civil de Québec (c/c art. 3), ao mencionar $a b$ initio a "personnalité juridique" inerente a todo o ser humano ${ }^{45}$.

Ambos os códigos prevêem a possibilidade de disposição do próprio corpo, sempre gratuita, com objetivo científico ou altruístico, mas o art. 14 do novo Código Civil brasileiro apenas menciona a hipótese post mortem, que na codificação québécoise é tratada especificamente nos arts. 42 a 49 . O art. 13 do diploma brasileiro é que se refere ao caso de disposição do próprio corpo durante a vida; nesse aspecto, o Código Civil de Québec parece ter optado por maior amplitude e precisão, enquanto o diploma brasileiro se norteou por uma preocupação aparentemente mais protetiva, tomando como regra a proibição de tal ato (v. a expressão "é defeso"), como se verifica abaixo:

\section{CÓDIGOCIVILDEQUÉBEC}

25. L'aliénation que fait une personne d'une partie ou de produits de son corps doit être gratuite; elle ne peut être répétée si elle présente un risque pour la santé. L'expérimentation ne peut donner lieu à aucune contrepartie financière hormis le versement d'une indemnité en compensation des pertes et des contraintes subies.

${ }^{45} \mathrm{Em}$ ambos os ordenamentos, cabe lembrar, a "iluminação" de tais dispositivos pelos valores consubstanciados nas respectivas Constituições é ponto essencial. No caso específico do Brasil, adquirem especial relevo os direitos fundamentais constantes do art. 5. da Constituição de 1988, bem como a consagração, já no art. 1., III, da dignidade da pessoa humana como um dos fundamentos do Estado brasileiro. Sobre o chamado "direito civil constitucional", v. supra, nota 7.

Revista da Faculdade de Direito da UFRGS, v. 21, Março/2002

\section{CÓDIGOCIVIL BRASILEIRO}

Art. 13. Salvo por exigência médica, é defeso o ato de disposição do próprio corpo, quando importar diminuição permanente da integridade física, ou contrariar os bons costumes.

A seguir, trata o Código Civil de Québec, em seus arts. 32 a 34 , da proteção específica dos direitos da criança. O diploma brasileiro, contudo, abstém-se de dispor sobre a matéria, tendo em vista que, a esse respeito, já vigora em nosso país o Estatuto da Criança e do Adolescente (Lei 8.069, de 13 de julho de 1990).

Tanto um quanto outro código, porém, afirmam a preocupação com o respeito à reputação e à vida privada, como um dos desmembramentos básicos compreendidos entre os direitos da personalidade. $\mathrm{O}$ diploma québécois regula a matéria em seus arts. 35 a 41 , em capítulo próprio, enquanto o Código Civil brasileiro lhe reserva $o$ art. 21:

\section{CÓDIGOCIVILDEQUÉBEC}

35. Toute personne a droit au respect de sa réputation et de sa vie privée. Nulle atteinte ne peut être portée à la vie privée d'une personne sans que celle-ci ou ses héritiers y consentent ou sans que la loi l'autorise.

\section{CÓDIGOCIVIL BRASILEIRO}

Art. 21. A vida privada da pessoa natural é inviolável, e o juiz, a requerimento do interessado, adotará as providências necessárias para impedir ou fazer cessar ato contrário a esta norma.

Sem paralelo no direito brasileiro, cabe sinalar, é o rol exemplificativo de situações que podem ser consideradas como atentatórias à vida privada, a fim de auxiliar a tarefa de interpretação do alcance do art. 35 pelo aplicador, conforme se lê no art. 36 do Código Civil de Québec:

36. Peuvent être notamment considérés comme des atteintes à la vie privée d'une personne les actes suivants:

$1^{\circ}$ Pénétrer chez elle ou y prendre quoi que ce soit;

$2^{\circ}$ Intercepter ou utiliser volontairement une communication privée;

$3^{\circ}$ Capter ou utiliser son image ou sa voix lorsqu'elle se trouve dans des lieux privés;

$4^{\circ}$ Surveiller sa vie privée par quelque moyen que ce soit;

$5^{\circ}$ Utiliser son nom, son image, sa ressemblance ou sa voix à toute autre fin que l'information légitime du public;

$6^{\circ}$ Utiliser sa correspondance, ses manuscrits ou ses autres documents personnels.

Ainda dentro do livro referente às pessoas, a nova codificação québécoise trata do estado das pessoas (arts. 50 a 152) e da capacidade (arts. 153 a 297).

No que tange a esses tópicos, a fim de ilustração, pode-se destacar o estabelecimento da maioridade aos dezoito anos (art. 153), à semelhança do que dispõe o art. 5. do novo Código Civil brasileiro, na redação modificada pelo Senado Federal, que reduz a idade-limite atual (vinte e um anos, segundo o art. 9. do diploma de 1916). Uma inovação digna de nota, implementada pelo novo Código Civil de Québec, é a permissão expressa da tutela remunerada (arts. 183 e 184), que antes era vedada pelo Code Civil du Bas-Canada; assim, aproxima-se da situação brasileira, onde é lícito que o tutor perceba "remuneração proporcional à importância dos bens administrados", salvo o caso de tutela de menores abandonados (art. 1.752, caput, do novo Código Civil brasileiro, que mantém os termos do art. 431 , caput, do diploma anterior). 
Afinal, há o regramento das chamadas personnes morales (arts. 298 a 364 do Código Civil de Québec), que podem ser de direito público ou de direito privado. Aqui se sublinha a previsão relativa à desconsideração da pessoa jurídica, em situações de fraude, abuso de direito ou violação de regra de ordem pública, que encontra paralelo no novo Código Civil brasileiro:

\section{CÓDIGOCIVILDEQUÉBEC}

316. En cas de fraude à l'égard de la personne morale, le tribunal peut, à la demande de tout intéressé, tenir les fondateurs, les administrateurs, les autres dirigeants ou les membres de la personne morale qui ont participé à l'acte reproché ou en ont tiré un profit personnel responsables, dans la mesure qu'il indique, du préjudice subi par la personne morale.

317. La personnalité juridique d'une personne morale ne peut être invoquée à l'encontre d'une personne de bonne foi, dès lors qu'on invoque cette personnalité pour masquer la fraude, l'abus de droit ou une contravention à une règle intéressant l'ordre public.

\section{CÓDIGOCIVIL BRASILEIRO}

Art. 50. Em caso de abuso da personalidade jurídica, caracterizado pelo desvio de finalidade, ou pela confusão patrimonial, pode o juiz decidir, a requerimento da parte, ou do Ministério Público quando lhe couber in tervir no processo, que os efeitos de certas e determinadas relações de obrigações sejam estendidos aos bens particulares dos administradores ou sócios da pessoa jurídica.

É oportuno apontar, quanto à administração dos bens da sociedade, o dispositivo do art. 1.011 do novo Código Civil brasileiro, compreendido dentro do livro pertinente ao direito de empresa. Estatui o mencionado artigo que "o administrador da sociedade deverá ter, no exercício de suas funções, o cuidado e a diligência que todo homem ativo e probo costuma empregar na administração de seus próprios negócios", expressando, com termos idênticos mas em âmbito mais lato, o mesmo dever de diligência a que se refere o art. 153 da Lei de Sociedades Anônimas (Lei 6.404, de 15 de dezembro de $1976)^{46}$. Trata-se de outro caso de incidência, marcadamente, do princípio da boa-fét7 .

\section{B) Família e sucessões}

No que se refere ao direito de família, o Código Civil de Québec segue as linhas do desenvolvimento atual da matéria, partindo da igualdade entre os cônjuges e vedando qualquer diferenciação entre filhos legítimos e ilegítimos, como se verá. No tratamento do direito sucessório, rumou-se a um menor formalismo quanto ao testamento, além de outras disposições que serão abordadas oportunamente.

Cabe salientar, antes de tudo, que o tratamento de algumas matérias relativas ao direito de família, como casamento e divórcio, é de competência federal, segundo o art. 91 do Acte de l'Amérique du Nord Britannique (1867), que foi mantido pela Lei Constitucional de $1982^{48}$. Assim, nesses assuntos, o Código Civil de Québec apenas previu expressamente o que já fora reconhecido e praticado em todo o Canadá; em outros tópicos, por outro lado, concernentes à competência provincial (arts. 92

46 O referido dispositivo não foi alterado pela recente reforma empreendida com a Lei 10.303 , de 31 de outubro de 2001.

47 V. supra, parte I, B.

48 V. supra, introdução, nota 4.

Revista da Faculdade de Direito da UFRGS, v. 21, Março/2002 e 93), o legislador québécois teve autonomia para regular a matéria ao seu modo, por assim dizer ${ }^{49}$.

Isso posto, pode-se realçar, desde logo, as disposições do Código Civil de Québec relativas ao instituto do casamento. $\mathrm{O}$ art. $365 \mathrm{faz}$ referência expressa ao fato de ocorrer casamento apenas entre homem e mulher, afastando a possibilidade de sua celebração entre pessoas do mesmo sexo; em atenção ao disposto constitucionalmente, uma modificação nesse particular só pode ser realizada em âmbito federal, sendo defeso aos elaboradores da codificação provincial dispor de modo diverso. Também o Código Civil brasileiro vislumbra tão-somente o casamento heterossexual, em consonância com o que estatuía o diploma de 1916. A igualdade entre os cônjuges, porém, foi consagrada no art. 226, § 5., da Constituição de $1988^{50}$ e devidamente respeitada na elaboração da nova codificação brasileira:

\section{CÓDIGOCIVIL DEQUÉBEC}

365. Le mariage doit être contracté publiquement devant un célébrant compétent et en présence de deux témoins. Il ne peut l'être qu'entre un homme et une femme qui expriment publiquement leur consentement libre et éclairé à cet égard.

\section{CÓDIGOCIVIL BRASILEIRO}

Art. 1.565. Pelo casamento, homem e mulher assumem mutuamente a condição de consortes, companheiros e responsáveis pelos encargos da família.

Interessante notar a coincidência das soluções adotadas pelos diplomas ora estudados quanto ao regime legal de bens. Ambos indicam, à falta de convenção, a prevalência do regime da comunhão parcial (ou de aqüestos), conforme segue:

\section{CÓDIGOCIVILDEQUÉBEC}

432. Les époux qui, avant la célébration du mariage, n'ont pas fixé leur régime matrimonial par contrat de mariage sont soumis au régime de la société d'acquêts.

\section{CÓDIGOCIVIL BRASILEIRO}

Art. 1.640. Não havendo convenção, ou sendo ela nula ou ineficaz, vigorará, quanto aos bens entre os cônjuges, o regime da comunhão parcial.

Cabe sinalar, contudo, que o art. $438 \mathrm{do}$ Código Civil de Québec admite a modificação do regime de bens a qualquer tempo, enquanto o art. 1.639, § 2., do novo diploma brasileiro se

4 Segundo os arts. 91 a 93 do Acte de l'Amérique du Nord Britannique, são matérias de competência federal: casamento, divórcio, direitos autorais, serviço postal, direito financeiro, telecomunicações, direito dos autóc-
tones etc. A competência provincial, por sua vez, abrange principalmente: propriedade e direitos civis dentro da provincia, administração da justiça dentro da província, taxação dentro da província, hospitais, instituida provincia, administração da justiça dentro da província, taxação dentro da província, hospitais, institui-
côs municipais, materias de interesse local e educação. Desnecessário frisar a importância que a repartição de çōes municipais, materrias de interesse local e educação. Desnecessário frisar a importância que a repartição de
competências invariavelmente possui no âmbito de discussão quanto ao federalismo, sendo marcante tal circunstância na realidade canadense.

so Discute-se, no caso brasileiro, se a Constituição de 1988 permite ou não o casamento homossexual, considerando-se que a redação do art. 226 , $\S \S 3$. e 5., parece prever apenas a sociedade conjugal entre um homem uma mulher. Uma interpretação feita à luz dos direitos fundamentais consagrados no art. 5. da Constituição, no entanto, pode conduzir ao reconhecimento, se não do casamento, pelo menos da união estável entre pessoas do mesmo sexo. 
apresenta mais rígido, admitindo apenas a sua alteração parcial, "mediante autorização judicial em pedido motivado de ambos os cônjuges, apurada a procedência das razões invocadas e ressalvados os direitos de terceiros". Tal dispositivo não encontra paralelo em nosso Código Civil de 1916, nem foi originalmente previsto no Projeto da codificação atual, mas introduzido num segundo momento, pela Emenda n. 284 do Senado Federal.

Característico do diploma québécois, em consonância com a consagração da fiducie, como instituto erigido à semelhança do trust inglês ${ }^{51}$, é o estabelecimento, com o casamento, de um patrimoine familial, formado por alguns bens dos cônjuges ${ }^{52}$. Um detalhe fundamental: não se perscruta, aqui, de quem é o direito de propriedade sobre tais bens, porquanto tem supremacia justamente a concepção de patrimônio, mais próxima dos moldes do estate anglo-saxão $0^{53}$.

Vale transcrever, para que melhor se compreenda o alcance desse instituto, o seguinte dispositivo:

415. Le patrimoine familial est constitué des biens suivants dont l'un ou l'autre des époux est propriétaire: les résidences de la famille ou les droits qui en confèrent l'usage, les meubles qui les garnissent ou les ornent et qui servent à l'usage du ménage, les véhicules

automobiles utilisés pour les déplacements de la famille et les droits accumulés durant le mariage au titre d'un régime de retraite.

Entrent également dans ce patrimoine, les gains inscrits, durant le mariage, au nom de chaque époux en application de la Loi sur le régime de rentes du Québec ou de programmes équivalents.

Sont toutefois exclus du patrimoine familial, si la dissolution du mariage résulte du décès, les gains visés au deuxièmealinéa ainsi que les droits accumulés au titre d'un régime de retraite régi ou établi par une loi qui accorde au conjoint survivant le droit à des prestations de décès.

Sont également exclus du patrimoine familial, les biens échus à l'un des époux pa succession ou donation avant ou pendant le mariage.

(...)

Deve-se fazer referência, ainda, à proibição expressa de contrato de maternidade ou de gestação por outrem (i.e., contrato de "barriga de aluguel" e afins), conforme dispõem os arts. 538 a 541 do Código Civil québécois. Quanto à adoção, de outra feita, resta legalmente consagrado o direito que possui o adotado de saber a qualquer tempo, quem são seus pais biológicos, uma vez que predomina - como irradiação do direito geral da personalidade ${ }^{55}$ - o direito à identidade pessoal.

Chegamos, então, ao direito sucessório

Primeiramente, tanto o art. $613 \mathrm{~d}$ codificação québécoise quanto o art. 1.785 do novo Código Civil brasileiro estatuem que abertura da sucessão se dá no lugar do último domicílio do falecido.

Ratificando a importância emprestada noção de patrimônio, reza o art. 614 do diplom canadense que os bens da sucessão formam "un seul patrimoine", com significado próximo ao "todo unitário" referido no art. 1.791 do novo Código Civil brasileiro ${ }^{56}$, mutatis mutandi, como se verifica abaixo:

\section{CÓDIGOCIVILDEQUÉBEC}

614. La loi ne considère ni l'origine ni la nature des biens pour en régler la succession; tous ensemble, ils ne forment qu'un seu patrimoine.

${ }^{51}$ V. supra, parte I, A, nota 16.

${ }^{52}$ A introdução desse instituto no direito québécois ocorreu, em verdade, já no ano de 1984, durante as reformas então realizadas. O Código Civil veio, posteriormente, apenas recepcionar e melhor desenvolver a figura do patrimoine familial.

${ }_{53}^{5}$ De fato, propriedade e property não são conceitos equivalentes, como bem demonstra DAVID, $O$ direito cit., pp. 95 e ss. A idéia continental de propriedade seria melhor traduzida pelo termo ownership, enquanto haveria uma proximidade (não uma equivalência!) entre patrimônio e estate (compreendido, este, como o conjunto de interesses a incidir sobre um ou mais bens).

Quanto à posse (possession) no direito inglês e sua relação com a property e a ownership, v. em especial o estudo de THUNIS et al., À la recherche de la possession en droit anglais, Revue Internationale de Droit Comparé, Paris, Société de Législation Comparée, jan.-mar. 2000, n. 1, pp. 77-100.

${ }^{54} \mathrm{Em}$ breve análise do tratamento dado ao tema pelo Projeto do novo Código Civil brasileiro, como "composição entre o bem de familia do direito americano (home stead) e o 'fundo patrimonial' do direito italiano", $v$. COUTO E SILVA, $O$ direito civil cit., p. 28

Revista da Faculdade de Direito da UFRGS, v. 21, Março/2002
Páragrafo único. Até a partilha, o direito dos co-herdeiros, quanto à propriedade $\mathrm{e}$ posse da herança, será indivisível, e regular-seá pelas normas relativas ao condomínio.

Deve-se lembrar que, no ordenamento jurídico brasileiro, justificando a menção a "normas relativas ao condomínio" feita no parágrafo único do artigo supracitado do novo Código Civil, o direito à sucessão aberta é legalmente equiparado aos bens imóveis (art. 80, II do diploma de 2002; art. 44,III, da codificação de 1916).

De modo geral, as disposições do Código Civil de Québec rumam a um menor formalismo no que tange à elaboração de testamentos (e.g., art. 726). Também quanto às cláusulas testamentárias, o legislador québécois parece ter concedido um maior âmbito de autonomia ao testador, em cotejo com as respectivas previsões do Código Civil brasileiro. Com efeito, ao tratar das novas regras deste diploma em matéria de sucessões, afirma Reale que o testador "deve explicitar o motivo que o leva a estabelecer a cláusula limitadora do exercício de direitos pelo seu herdeiro, podendo o juiz, em certas circunstâncias, apreciar a matéria para verificar se procede a justa causa invocada" 57 .

O diploma de Québec prevê, em seu art. 749 , uma situação que apresenta similaridades com aquela descrita no art. 1.809 do novo Código Civil brasileiro - i.e., se um herdeiro vier a falecer antes de declarar se aceita ou não a herança, tal poder passa aos seus próprios herdeiros, nas condições legalmente previstas. $O$ código québécois, contudo, no dispositivo acima apontado, vislumbra a representação de um herdeiro falecido antes do testador.

Art. 1.791. A herança defere-se com um todo unitário, ainda que vários sejam os herdeiros.

${ }^{55}$ V. supra, parte II, A.

${ }^{56}$ A título de curiosidade: o termo "totalidade" fora introduzido pela Emenda n. 355 do Senado Federal, mas no fim das contas acabou prevalecendo a expressão "todo unitário", conforme a redação original do Projeto. 0 Código Civil de 1916, por sua vez, não continha vocábulo assemelhado.

${ }^{57}$ REALE, op. cit., p. 18 
Por último, cabe destaque à figura do liquidateur da sucessão, prevista no art. 783 e ss. do Código Civil de Québec, que vem substituir o cargo de exécuteur testamentaire, de alcance notadamente mais restrito. Parte-se, uma vez mais, da importação feita pelo legislador québécois do instituto inglês do trust, mediante a inclusão de um corpo de regras de aplicação geral quanto à administração de bens de outrem (art. 1299 e ss.) $)^{58}$, porquanto é na mesma noção de patrimônio (art. 614) que se baseiam os direitos e deveres do liquidateur sucessório.

\section{C) Bens}

O que primeiro chama a atenção do estudioso, no livro do Código Civil de Québec destinado aos bens, em comparação com o antigo Code Civil du Bas Canada, é a ampliação do conceito de propriedade: antes, abrangia apenas as coisas (choses, things); agora, o termo utilizado é, justamente, bens (biens, property).

Como se sabe, Québec é uma província bilingüe, sendo sua legislação publicada sempre nas duas línguas oficiais, ou seja, em inglês e francês. Ambas vigem com força de lei, de modo que se pode antever o esforço empreendido na tradução de algumas expressões jurídicas, que não apresentem significado paralelo na outra língua - principalmente se for considerado o fato de não haver apenas duas linguagens diferentes, no caso, mas duas famílias de direito fundamentalmente distintas. É interes- sante, por esse motivo, transcrever o texto do art. 947 do Código Civil québécois em ambas as línguas oficiais: et de disposer librement et complètement d'un bien, sous réserve des limites et des conditions d'exercise fixées par la loi.

Elle est suscetible de modalités et de démembrements. Ownership is the right to use, enjoy and dispose of property fully and freely, subject to the limits, and conditions for doing so determined by law.

Ownership may be in various modes and dismemberments.

A doutrina registrou essa alteração, de "coisas" para "bens", e meditou sobre seu significado: seria um mero lapsus linguae? ou o legislador teria voluntariamente ampliado o conceito de propriedade, para abranger também os bens incorpóreos? Ora, a linguagem utilizada pelo legislador é clara, não se presta a maiores lucubrações, de modo que, apesar da relativa polivalência do termo biens (property), o alcance do conceito inegavelmente se alargou ${ }^{59}$. Nesse sentido, deve-se conectar o conceito do art. 947 com o que estabelece o art. 899 , ao abrir o livro referente aos bens: "Les biens, tant corporels qu'incorporels, se divisent en immeubles et en meubles".

O novo Código Civil brasileiro, em contraste, não apresenta propriamente um conceito de propriedade. No entanto, pode-se depreendê-lo do disposto no art. 1.228 - que utiliza, por sua vez, o termo "coisa" 60 .
La propriété est le droit d'user, de jouir

\section{V. supra, parte I, B.}

59 A esse respeito, $v$. especialmente BRIERLEY, Regards sur le droit des biens dans le nouveau code civil du Québec, Revue Internationale de Droit Comparé, Paris, Société de Législation Comparée, jan.-mar. 1995, n. 1 , pp. 35-36.

6o É oportuno apontar que, enquanto o Livro II (Dos bens) da Parte Geral se refere sempre a "bens", o Livro III (Do direito das coisas) da Parte Especial do novo Código Civil brasileiro utiliza tão-somente o termo "coisa". O mesmo ocorre, com poucas diferenças, no regramento da codificação de 1916 - v. a distinção terminológica feita por PONTES DE MIRANDA, Tratado de direito privado, 2. ed., Rio de Janeiro, Borsoi, 1954, t. II, \& $118,1$.
A estruturação adotada pelo Código Civil de Québec faz a distinção entre modalidades e desmembramentos da propriedade, conforme segue:

a) são consideradas modalidades da propriedade a copropriedade por indivisão (art. 1.012 e ss.) e a copropriedade divisível (art. 1.038 e ss.), além da propriété superficiaire (art. $1.110 \mathrm{e} \mathrm{ss}$.)

b) constituem desmembramentos da propriedade, por sua vez, o usufruto (art. 1.120 ss.), o uso (art. 1.172 e ss.), as servidões (art. 1.177 e ss.) e a enfiteuse (art. 1.195 e ss.).

Dentre as modalidades supramencionadas (item $a$ ), é pertinente ressaltar a previsão da propriété superficiaire, que vem de encontro às disposições do novo Código Civil brasileiro quanto ao direito de superfície, em seu art. 1.369 e ss. Aqui, como assevera José Carlos Moreira Alves, trata-se de conceder novo enfoque a um antigo instituto do ordenamento jurídico luso-brasileiro - agora sob a influência da figura da "concessão de uso", oriunda do direito administrativo ${ }^{61}$. O Código Civil de 1916 todavia, não contemplava o direito de superfície.

A fim de comparar a redação dos dispositivos que introduzem o instituto na codificação québécoise e nodiploma brasileiro, demarcando suas similaridades, passa-se a transcrevê-los:

\section{CÓDIGOCIVILDEQUÉBEC}

1.011. La propriété superficiaire est celle des constructions, ouvrages ou plantations

${ }^{61}$ REALE, op. cit., p. 84

${ }^{62}$ BRIERLEY, p.ex., ao discutir o alcance da propriété superficiaire, causa certa estranheza ao afirmar que "le nouveau Code civil va encore plus loin dans cette direction en laissant entrevoir la possibilité de la cession d'un volume d'air qui surplombe le terrain" (op. cit., p. 38).

${ }^{63}$ A necessidade da inclusão, no rol dos direitos reais, da promessa de compra e venda é defendida por REALE, não obstante a jurisprudência já há muitos anos pacificada, devido ao fato de que tais direitos "não podem deixar de ser taxativamente enumerados" (op. cit., p. 39).

Revista da Faculdade de Direito da UFRGS, v. 21, Março/2002 situés sur l'immeuble appartenant à une autre personne, le tréfoncier.

\section{CODIGOCIVIL BRASILEIRO}

rt. 1.369. O proprietário pode conceder a outrem o direito de construir ou de plantar em seu terreno, por tempo determinado, mediante escritura pública devidamente inscrino Registro de Imóveis.

Trata-se, em suma, do mesmo instituto jurídico, consagrado tanto lá quanto cá. Se há algumas nuanças próprias de um ou outro ordenamento (como de fato se verifica, p.ex., na previsão de um prazo máximo de cem anos pelo Código Civil de Québec) ${ }^{62}$, tais características não chegam a afetar o núcleo do mesmo direito de superfície.

No que diz respeito aos desmembramentos da propriedade arrolados no diploma québécois (item $b$ ), são basicamente os mesmos que prevê o Código Civil brasileiro. Neste, contudo - ao lado das servidões, do usufruto e (anda a presença da habiarts. 1.414 a 1.416), como especificação o uso para moradia, e, logo a seguir, menciona-se igualmente o direito real do promitente 1.418), quando não pactuado arrependimento ${ }^{63}$.

Por fim, o estudioso do novo Código Cril brasileiro depara-se com a proibição expressa de constituição de enfiteuses e subenfiteuses, "subordinando-se as existentes, 
vil anterior, Lei 3.071, de 1. de janeiro de 1916, e leis posteriores" (art. 2.038). Cremos que se justifica a escolha dos elaboradores do respectivo Anteprojeto, uma vez que a figura da enfiteuse, ao menos em nosso país, indubitavelmente perdeu sua relevância prática ${ }^{64}$.

Sobre a noção de patrimoine d'affectation já se teceu algumas considerações anteriormente ${ }^{65}$, bem como se ressaltou sua importância ímpar como "le concept fondamental qui permet au législateur de mettre en place un système de fiducie qui remplit les mêmes fonctions que les trusts de la common law, mais en ayant recours à des concepts connus en droit civil" ${ }^{66}$. De fato, o Código Civil de Québec reconhece duas espécies de patrimoines d'affectation: a fundação (art. 1.256 e ss.) e a fiducie (art. 1.260 e ss.)

O conceito de fundação apresentado pelo art. 1.256 do diploma québécois basicamente não difere do que se lê na Parte Geral do novo Código Civil brasileiro, como se verifica abaixo:

\section{CÓDIGOCIVILDEQUÉBEC}

1.256. La fondation résulte d'un acte par lequel une personne affecte, d'une façon irrévocable, tout ou partie de ses biens à une fin d'utilité sociale ayant un caractère durable.

La fondation ne peut avoir pour obje essentiel la réalisation d'un bénéfice ni l'exploitation d'une entreprise.

\section{CÓDIGOCIVIL BRASILEIRO}

Art. 62. Para criar uma fundação, o seu instituidor fará, por escritura pública ou testamento, dotação especial de bens livres, especificando o fim a que se destina, e declarando, se quiser, a maneira de administrá-la.

Parágrafo único. A fundação somente poderá constituir-se para fins religiosos, morais, culturais ou de assistência.

$\mathrm{O}$ que resulta francamente peculiar no direito privado québécois, expondo de maneira formidável as relações cambiáveis mas sempre operantes entre o sistema jurídico francês e o sistema de common law na sociedade localpara regozijo dos estudiosos de direito comparado -, é o regramento legal da fiducie, nos moldes do tradicional instituto inglês do trust $t^{67}$.

Na realidade, as raízes dessa figura não se encontram sequer na common law propriamente dita, mas na equity, porquanto a valorização do trust surgiu como remédio jurisprudencial para contornar algumas situações injustas que começaram a advir da aplicação formalista das regras de common law ${ }^{68}$. Apresentar uma definição doutrinária desse ins-

${ }^{64}$ Nesse sentido, REALE qualifica a enfiteuse como "velha e condenada instituição", ratificando o entendimento de Orlando Gomes, cujo Projeto de codificação também visava a extinguir, apenas de modo mais prolongado no tempo, aquele mesmo "instituto obsoleto, em franco desuso" (apud: REALE, op. cit., p. 131).

${ }_{65}$ V. supra, parte I, B.

${ }^{66}$ JOBIN, Le nouveau cit., p. 917

${ }^{67} \mathrm{~V}$. supra, parte I, A, nota 16

${ }_{68}$ Para maior aprofundamento na evolução histórica do trust, v. a interessante digressão de DAVID, O direito cit., p. 102 e ss. Um estudo minucioso da fiducie no Código Civil de Québec é realizado por BRIERLEY, op. cit., pp. $2-48$

Revista da Faculdade de Direito da UFRGS, v. 21, Março/2002

Em síntese, de acordo com o art. 2.650

tituto, como já se percebe, constitui tarefa delicada $^{69}$, que foge, ademais, do tema específico deste trabalho, razão pela qual resulta suficiente a mera transcrição do art. 1.260 do Código Civil de Québec:

La fiducie résulte d'un acte par lequel une personne, le constituant, transfère de son patrimoine à un autre patrimoine qu'il constitue, des biens qu'il affecte à une fin particulière et qu'un fiduciaire s'oblige, par le fait de son acceptation, à détenir et à administrer.

As aplicações práticas da fiducie são inúmeras, manifestando-se em diversas áreas do direito privado, como se conclui a partir dos séculos de experiência jurídica que o instituto paralelo do trust sentiu na Inglaterra. Com efeito, seu alcance vai desde a proteção dos interesses pecuniários de incapazes, passando pela administração de uma sociedade ou associação, até a partilha de bens nas sucessões, e isso para ficar-se apenas em três exemplos; em todos eles, contudo, identifica-se a mesma idéia básica da constituição de um patrimoine fiduciaire, completamente autônomo e distinto dos patrimônios individuais do constituinte, do fiduciário ou do beneficiário ${ }^{70}$.

A sistematização da matéria adotada pelo Código Civil de Québec consagra, além do Livro IV, dedicado aos bens, um tratamento apartado para o regime das garantias, no Livro VI. Destarte, o legislador reconheceu duas formas distintas - as prioridades e as hipotecas. da atual codificação, recebe o nome de prioridade (priorité) ) $^{71}$ todo direito não-real, estabelecido por lei, de ser preferido frente a outros credores - mesmo que estes sejam hipotecários. Seu número é limitado (art. 2.651), pois deve ser prevista em lei: é o que ocorre, p.ex., com os créditos fiscais.

As garantias reais, por sua vez, convergem todas na figura da hipoteca (hypotèque), em conseqüência da unificação de regime realizada pelo legislador, a fim de conceder tratamento igualitário a todos os devedores que prestam garantia. É, em outras palavras, a vigência daquilo que Jobin chama de "présomption d'hypotèque" 72 , a causar uma dilatação formidável do alcance dessa garantia real: com efeito, o Código Civil de Québec prevê tanto a hipoteca convencional quanto a legal. Nesta, incide simplesmente o rol de credores especificados no art. 2.724; na hipoteca convencional, por sua vez, passam a conviver três formas distintas:

a) a hipoteca imobiliária (art. 2.693 e ss.), que nada mais é do que a tradicional garantia hipotecária, não trazendo inovações dignas de nota;

b) a hipoteca mobiliária (art. 2.696 e ss.), que constitui a grande novidade do Código, podendo incidir com ou sem transferência da posse do bem gravado ${ }^{73}$. É um instituto consideravelmente maleável, uma vez que

${ }^{69}$ DAVID, p.ex., prefere apenas transcrever a fórmula proposta pelo historiador do direito inglês F. W. Maitland: "Quando uma pessoa tem direitos que deve exercer no interesse de outra ou para a realização de um objetivo em causa, sendo chamada de trustee" (apud: O direito cit., pp. 99-100)

${ }^{70}$ BRIERLEY, op. cit., p. 45 .

${ }^{71}$ BRIERLEY, op. cit., p. 39

72 JOBIN, Le nouveau cit., p. 916

${ }^{73}$ Conforme o art. 2.665 do Código Civil de Québec, no primeiro caso (i.e., quando a hipoteca mobiliária se dá com transferência da posse do bem gravado), ocorre a identificação dessa nova figura com a garantia pignoratícia (gage). 
pode abranger não apenas um móvel, mas ainda uma universalidade de bens e até animais;

c) a hipoteca aberta (art. 2.715 e ss.), na qual alguns efeitos são suspensos até o momento em que o credor resolve "fechar" a sua garantia, em face do descumprimento de alguma obrigação por parte do devedor ou do constituinte. Cabe ressaltar que tal característica tem de estar expressa no ato de constituição da hipoteca.

Todavia, se é notável a liberalidade do novo Código Civil de Québec quanto à formação de garantias hipotecárias, houve a sensível preocupação, em contrapartida, de estabelecerse regras estritas no que se refere à sua realização.

Nesse sentido, como já se referiu anteriormente, o legislador incluiu um corpo específico de regras sobre o exercício dos direitos hipotecários (arts. 2.748 e ss.) $)^{74}$, a consagrar "un ensemble de mesures de protection ou d'équité imposées au créancier qui veut exercer ses droits en vertu d'une hypothèque" ${ }^{75}$. Assim, e.g., 0 art. 2.757 exige do credor que preste um préavis, de vinte ou de sessenta dias (dependendo de ser o bem móvel ou imóvel), ao devedor, a fim de que este possa remediar a situação dentro do período demarcado e, dessa forma, evitar o exercício das sanções cabíveis.

\section{D) Obrigações}

No campo das obrigações, encontra-se igualmente uma preocupação do legislador em

${ }^{74} \mathrm{~V}$. supra, parte I, B.

75 JOBIN, Le nouveau cit., p. 915.

${ }^{76}$ Entre os trabalhos mais recentes, v. JOBIN, La modernité du droit commun des contrats dans le code civil du Québec: Quelle modernité?, Revue Internationale de Droit Comparé, Paris, Société de Législation Comparée, jan.-mar. 2000, n. 1, pp. 49-76.

${ }^{7}$ GOMES, Direitos reais, 12. ed., Rio de Janeiro, Forense, 1997, pp. 133-134.

${ }^{78}$ Sublinhamos. Cabe apontar que o art. 916 está compreendido dentre as disposições a respeito dos bens (Livro IV), enquanto os seguintes já pertencem ao Livro V, referente às obrigações: o art. 1.433 trata dos efeitos dos contratos em geral, e o art. 1.708 traz a definiçâo legal do contrato de compra e venda (vente).

Revista da Faculdade de Direito da UFRGS, v. 21, Março/2002
916. Les biens s'acquièrent par contrat, par succession, par occupation, par prescription, par accession ou par tout autre mode prévu par la loi. (...)

1.433. Le contrat crée des obligations et quelquefois les modifie ou les éteint. En certains cas, il a aussi pour effet de constituer, transférer, modifier ou éteindre des droits réels.

1.708. La vente est le contrat par lequel une personne, le vendeur, transfère la propriété d'un bien à une autre personne, l'acheteur. moyennant un prix en argent que cette dernière s'oblige à payer. (...)

Nesse aspecto, o Código Civil brasileiro mantém o sistema tradicionalmente seguido em nosso país - i.e., aproximado à raiz romana -, segundo o qual são necessários para a transferência da propriedade tanto o título quanto o modo. De fato, nas legislações de influência romana, o título incorpora a causa da aquisição, diferenciando-se do sistema alemão, por sua vez, devido à abstração que este faz da causa do negócio jurídico dispositivo ${ }^{79}$.

Essas distinções entre os sistemas supracitados têm efeitos relevantíssimos quanto à separação dos planos obrigacional e real, que, inexistindo no direito francês, será absoluta no direito germânico e apenas relativa no direito brasileiro. É justamente por essa peculiaridade do direito brasileiro, conforme a lição de Clóvis do Couto e Silva, que o estudo da separação dos planos se reveste de especial pertinência: como o adimplemento, no caso, importa em transmissão da propriedade, a fase respectiva desloca-se do plano obrigacional para o plano real ${ }^{80}$ - o que não ocorre no sistema alemão, muito menos no sistema francês.

Isso posto, é mister citar os arts. $1.425 \mathrm{a}$ 1.432 do Código Civil de Québec, referentes à interpretação dos contratos, que dão valor predominante à intenção das partes sobre a literalidade do instrumento contratual, colocando-se no mesmo sentido do art. 112 do novo Código Civil brasileiro ${ }^{81}$. Este, contudo, por estar localizado na Parte Geral do diploma, bem como por mencionar "declarações de vontade", e não apenas "contrato", tem alcance semântico mais amplo.

\section{CÓDIGOCIVIL DEQUÉBEC}

1.425. Dans l'interprétation du contrat, on doit rechercher quelle a été la commune intention des parties plutôt que de s'arrêter au sens littéral des termes utilisés.

\section{CÓDIGOCIVIL BRASILEIRO}

Art. 112. Nas declarações de vontade se atenderá mais à intenção nelas consubstanciada do que ao sentido literal da linguagem.

Ambos os diplomas prevêem normas a respeito dos contratos por adesão. A codificação québécoise, contudo, vai mais além do que os arts. 423 e 424 do novo Código Civil brasileiro, dispondo especificamente a respeito

${ }^{79}$ GOMES, op. cit., p. 134. Para uma análise de fôlego da teoria da causa, em perspectiva histórica e com o aprofundamento das suas consequências, v. COUTO E SILVA, A obrigação como processo, São Paulo, José Bushatsky, 1976, p. 45 e ss. Especificamente quanto ao caráter causal da tradição no direito brasileiro, ensina 0 autor que "a aceitação do negócio jurídico de disposição como causal proveio da regra exarada no art. 622 do Código Civil (de 1916)..., por meio de hermenêutica integradora" (A obrigaçẫo cit., pp. 60-61). Com efeito, esse dispositivo é mantido pelo art. 1.268 do novo Código Civil brasileiro, cujo $\S 2$ 2. estatui: "Não transfere a propriedade a tradição, quando tiver por título um negócio jurííco nulo".

${ }^{80}$ COUTO E SILVA, A obrigą̧ão cit., p. 44.

${ }^{81}$ Quanto ao tratamento dado ao princípio da boa-fé pelos dois diplomas, v. supra, parte I, B 
da proteção jurídica do consumidor; no Brasil, como se sabe, a matéria é regida pelo Código de Defesa do Consumidor (Lei 8.078, de 11 de setembro de 1990) $)^{82}$. Nesse sentido, inclusive dando critérios para a identificação da abusividade de uma determinada cláusula contratual, ordenam os artigos do Código Civil de Québec a seguir transcritos ${ }^{83}$ :

1.432. Dans le doute, le contrat s'interprète en faveur de celui qui a contracté l'obligation et contre celui qui l'a stipulée. Dans tous les cas, il s'interprète en faveur de l'adhérent ou du consommateur

1.436. Dans un contrat de consommation ou d'adhésion, la clause illisible ou incompréhensible pour une personne raisonnable est nulle si le consommateur ou la partie qui y adhère en souffre préjudice, à moins que l'autre partie ne prouve que de explications adéquates sur la nature et l'étendue de la clause ont été données au consommateur ou à l'adhérent.

1.437. La clause abusive d'un contrat de consommation ou d'adhésion est nulle ou l'obligation qui en découle, réductible.

Est abusive toute clause qui désavantage le consommateur ou l'adhérent d'une manière excessive et déraisonnable. allant ainsi à l'encontre de ce qu'exige la bonne foi; est abusive, notamment. la clause si éloignée des obligations essentielles qui découlent des règle gouvernant habituellement le contrat qu'elle dénature celui-ci.

No ordenamento jurídico brasileiro, vige o art. 51 do Código de Defesa do Consumidor, que apresenta um rol de cláusulas contratuais relativas ao fornecimento de produtos e serviços que são nulas de pleno direito, devido ao seu caráter reconhecidamente abusivo. Diferem, portanto, as técnicas adotadas, uma vez que $o$ legislador québécois limitou-se a estabelecer uma cláusula geral, enquanto no Brasil prevaleceu uma lista exemplificativa de situações nas quais a abusividade se manifesta, acarretando a nulidade das respectivas cláusulas.

Merece destaque, de outra parte, o regramento da responsabilidade civil por danos. O Código Civil de Québec divide as disposições gerais a respeito em dois artigos, conforme se vislumbre responsabilidade extracontratual ou contratual ${ }^{84}$ :

1.457. Toute personne a le devoir de respecter les règles de conduite qui, suivant les circonstances, les usages ou la loi, s'imposent à elle, de manière à ne pas causer de préjudice à autrui.

Elle est, lorsqu'elle est douée de raison et qu'elle manque à ce devoir, responsable du préjudice qu'elle cause par cette faute à autrui et tenue de réparer ce préjudice, qu'il soit corporel, moral ou matériel.

Elle est aussi tenue, en certains cas, de réparer le préjudice causé à autrui par le fait ou la faute d'une autre personne ou par le fait des biens qu'elle a sous sa garde.
1.458. Toute personne a le devoir d'honorer les engagements qu'elle a contractés.

Elle est, lorsqu'elle manque à ce devoir, responsable du préjudice, corporel. moral ou matériel, qu'elle cause à son cocontractant et tenue de réparer ce préjudice; ni elle ni le cocontractant ne peuvent alors se soustraire à l'application des règles du régime contractuel de responsabilité pour opter en faveur de règles qui leur seraient plus profitables.

Fica legalmente garantido, pois, o ressarcimento pleno dos danos, sejam físicos, morais ou materiais, à semelhança do que ocorre no $\mathrm{Brasil}^{85}$; em nosso país, contudo, não se faz comumente essa distinção tripartite, porquanto os danos físicos estariam compreendidos, a priori, dentro das outras duas categorias. Parece interessante, afinal, o entendimento adotado pelo Código Civil de Québec: trata-se realmente de lesões de natureza diversa.

É diverso, ainda, a abordagem concedida à matéria da responsabilidade civil pelos dois diplomas. Enquanto a codificação québécoise introduziu um artigo para a responsabilidade extracontratual (art. 1.457) e outro para a responsabilidade contratual (art 1.458), para depois adentrar as disposições específicas, o Código Civil brasileiro seguiu a tradição pátria de prever uma norma de caráter geral - o art. 927 , que faz remissão aos arts. 186 e $187^{86}$. A distin- ção entre ambas as espécies de responsabilidade civil, todavia, é reconhecida no Brasil pela doutrina e pela jurisprudência.

Digno de nota, no mesmo art. 1.457 do Código Civil de Québec, é a menção express aos usos (usages) como fonte de regras jurídicas de conduta, a ensejar eventualmente a responsabilização civil da parte que não os observar. O ordenamento jurídico brasileiro não possui norma equiparável a essa, mas o novo Código Civil prevê, no parágrafo único do art. 927, a responsabilização independente de culpa não apenas nos casos definidos em lei, mas também "quando a atividade normalmente desenvolvida pelo autor do dano implicar, por sua natureza, risco para os direitos de outrem". Para consumar tal análise, o aplicador deverá necessariamente levar em conta tanto a lei quanto as circunstâncias e os usos incidentes no caso concreto $^{87}$ - em última análise, o resultado será similar ao estabelecido no art. 1.457 do Código Civil de Québec.

No rol dos contratos nominados, cabe indicar o contrat d'entreprise ou de service (art. 2.098 e ss. do diploma québécois). Trata-se de figura aplicável às situações contempladas pelo novo Código Civil brasileiro dentro do âmbito do contrato de prestação de serviço (art. $593 \mathrm{e}$ ss.) $)^{88}$ e do contrato de empreitada (art. $610 \mathrm{e}$ ss.), na dependência de ser o objeto do negó-

${ }^{85}$ Se o Código Civil brasileiro não é tão explícito quanto ao cabimento de indenização por dano moral, apesar do disposto no art. 186, e considerando-se ainda o silêncio da codificação de 1916 a respeito, não deixa dúvida alguma o art. 5., X, da Constituição de 1988, que assegura expressamente ao lesado "o direito a indenização pelo dano material ou moral". Não há, em suma, o que se discutir sobre o assunto, restando dificuldades apenas no permanente problema da quantificação do dano moral.

${ }^{86} \mathrm{O}$ art. 186 do novo Código Civil brasileiro equivale aproximadamente ao art. 159 do diploma de 1916. Aquele, porém, prevê inclusive a comissão de dano exclusivamente moral como passível de configurar ato ilícito, bem como faz outras modificações significativas, cujo desenvolvimento foge ao objetivo deste trabalho.

${ }^{87}$ REALE, op. cit., p. 13

${ }^{88}$ A figura do contrato de prestação de serviço, em constante desenvolvimento jurisprudencial, vem substituir, com algumas regras diferenciadas, o outrora denominado contrato de "locação de serviço", assentado no ar. 1.216 e ss. do Código Civil de 1916. Sobre o tema, v. TIMM, Da prestação de serviços, Porto Alegre, Síntese, 1998 , passim.
${ }^{82}$ De fato, o art. 54 do Código de Defesa do Consumidor define o que se deve entender por "contrato de adesão". No entanto, neste trabalho se prefere a expressão "contrato por ades
contratual específico, mas de um modo de formação de contratos.

${ }^{83}$ Sublinhamos.

\section{${ }^{84}$ Sublinhamos.}

Revista da Faculdade de Direito da UFRGS, v. 21, Março/2002 
cio jurídico um serviço ou uma obra. Em síntese, o ordenamento pátrio faz tal distinção porque estatui regras e efeitos próprios a cada um desses contratos.

Em último lugar, é oportuno dar destaque à introdução da convenção de arbitragem na lista dos contratos típicos (art. 2.638 e ss. do Código Civil de Québec), a recepcionar o conjunto de regras instituídas com essa finalidade já em 1986, durante o processo de reforma da codificação então vigente. O legislador entendeu incluir uma definição desse instituto dentro do próprio diploma codificatório, conforme segue:

2.638. La convention d'arbitrage est le contrat par lequel les parties s'engagent à soumettre un différend né ou éventuel à la décision d'un ou de plusieurs arbitres, à l'exclusion des tribunaux.

O novo Código Civil brasileiro, em seu art. 853, admite nos contratos a cláusula compromissória, "para resolver divergências mediante juízo arbitral", mas remete o aplicador do direito à lei específica que regula a matéria (Lei 9.307, de 23 de setembro de 1996). Nãoparece razoável, enfim, seguindo a boa metodologia de direito comparado, julgar qual dos dois sistemas seria "o mais correto" nesse particular: são, apenas, opções legislativas diversas.

\section{Conclusão}

O cotejo do novo Código Civil de Québec com o novo Código Civil brasileiro justifica-se pelo fato de pertencerem, tanto um quanto outro diploma, a um mesmo momento histórico, posterior à promulgação de uma Constituição na década de $1980^{89}$. Não se quer negar, obviamente, que Canadá e Brasil experimen-

${ }^{89}$ v. supra, introdução.

As

Revista da Faculdade de Direito da UFRGS, v. 21, Março/2002 tem realidades diversas e possuam tradições distintas; pelo contrário, a comparação entre os dois documentos codificatórios não tem por fim eleger qual deles é "o melhor", mas sim estudar o modo pelo qual cada código tenta resolver normativamente os problemas práticos que se interpõem entre o jurista e a Justiça. Por vezes, os resultados variam; em outros pontos, coincidem: o essencial é, nas palavras de René David, a partir de uma análise comparativa, conhecer melhor o próprio direito nacional, para que então se possa considerar prudentemente a necessidade e o meio de seu aperfeiçoamento ${ }^{\circ 0}$.

Como se viu, o Código Civil de Québec apresenta diversas soluções jurídicas interessantes. Algumas, sem dúvida alguma, são próprias de sua circunstância geopolítica e histórica, como o constante intercâmbio jurídico-cultural que se estabelece entre a influência anglosaxã e a tradição originariamente francesa dessa província: a mais latente prova disso é a instituição da fiducie, oriunda da necessidade prática de regrar-se a figura do trust, vigente nas províncias anglófonas do Canadá, também no âmbito social québécois.

Outras soluções jurídicas, todavia, estão compreendidas dentro de um processo internacional - ou, ao menos, um processo que envolve a família de direito romano-germânico, dentre os quais está a França e, por ricochete, a província de Québec -, posterior à dolorida experiência das Grandes Guerras, mediante o qual os diferentes ordenamentos jurídicos passaram a identificar-se em torno de alguns princípios e direitos fundamentais. Ratifica esse consenso a edição de várias declarações e tratados internacionais, bem como a promulgação de um número elevado de Constituições nacionais com marcada preocupação axiológica. Sob essa óptica, pois, o Código Civil de Québec é um diploma sintonizado com o seu tempo e a sua realidade.

Após uma tal análise, acredita-se que a única conclusão a que se pode chegar é a de que o novo Código Civil brasileiro se encontra igualmente inserido no processo acima apontado, ainda ao recepcionar elementos próprios da tradição pátria, ainda ao inovar de modo distinto ao da codificação québécoise, ainda ao quem sabe? - equivocar-se eventualmente nas opções teóricas feitas, porque de erros nenhuma obra humana está isenta. De uma maneira ou de outra, os dois diplomas cotejados irmanam-se numa perspectiva menos individualista que a de seus antecessores, na sistemática mais aberta à irradiação dos valores constitucionais, na igual tarefa de reconstruir as normas centrais do direito civil para a realidade de agora.

Nesse sentido, nem que seja devido à sua antecedência cronológica, a vigência do Código Civil de Québec permite aos estudiosos do direito comparado - transcorrida a rica fase inicial de amadurecimento que a aplicação de toda e qualquer lei proporciona - traçar quais soluções jurídicas vingarão. Se estiverem atentos às pegadas ora deixadas na areia pela experiência québécoise, tanto melhor para os civilistas brasileiros, que a partir de janeiro de 2003 terão diante de si uma vereda semelhante.

\section{Obras consultadas}

\section{Obras de caráter introdutório}

CAENEGEM, R. C. van. Uma introdução histórica ao direito privado. Trad. por Carlos Eduardo Machado. São Paulo : Martins Fontes, 1995.

COUTO E SILVA, Clóvis do.A obrigação como processo. São Paulo : José Bushatsky, 1976.
DAVID, René. Os grandes sistemas do direito contemporâneo. Trad. por Hermínio A. Carvalho. 2. ed. São Paulo: Martins Fontes, 1993.

GUY, Stéphane. Codifications et consolidations législatives à l'étranger. Revue du Droit Public et de la Science Politique en France et à l'étranger. Paris : Librairie Générale de Droit e de Jurisprudence, mai.jun. 1998, n. 3, pp. 861-890.

HATTENHAUER, Hans. Conceptos fundamentales del derecho civil. Trad. por Gonzalo Hernández. Barcelona : Ariel, 1987.

MARTINS-COSTA, Judith. A boa-fé no direito privado. Sistema e tópica no processo obrigacional. São Paulo : Revista dos Tribunais, 1999.

PERLINGIERI, Pietro. Perfis do direito civil. Trad. por Maria Cristina De Cicco. 3. ed. Rio de Janeiro : Renovar, 1997.

PONTES DE MIRANDA, Francisco Cavalcanti. Tratado de direito privado. 2 . ed. Rio de Janeiro : Borsoi, 1954, t. II.

PRATA, Ana. A tutela constitucional da autonomia privada. Coimbra : Almedina, 1982.

RAISER, Ludwig. La Costituzione e il diritto privato. In: Il compito del diritto privato. Trad. por Marta Graziadei. Milão : Giuffrè, 1990,pp. 169-191.

WIEACKER, Franz. História do direito privado moderno. Trad. por A. M. Botelho Hespanha. 2. ed.Lisboa: Calouste Gulbenkian, 1993.

2.. Obras específicas sobre o Código Civil de Québec

BRIERLEY, John E. C. Regards sur le droit des biens dans le nouveau code civil du Québec. Revue Internationale de Droit Comparé. Paris : Société de Législation Comparée, jan.mar. 1995, n. 1, pp. 33-49. 
CANADÁ. Civil code of Québec. Internet : 2000. (http://www.lexum.umontreal.ca/ ccq/en/ index.html)

Code civil du Québec. Internet: 2000. (http://www.lexum umontreal.ca/ccq/fr/index.html)

Code civil du Québec. Editeur Officiel du Québec, 1991.

GÉLINAS, Marc. Les grands titres du code civi du Québec. Le Réseau Juridique du Québec. Internet: 1997. (http:// www.avocat.qc.ca/public/iiccqlignes.htm)

JOBIN, Pierre-Gabriel. La modernité du droi commun des contrats dans le code civil du Québec: Quelle modernité? Revue Internationale de Droit Comparé. Paris : Société de Législation Comparée, jan.-mar. 2000, n. 1, pp. 49-76.

Le droit transitoire et 1 code civil du Québec. Revue Trimestrielle de Droit Civil. Paris : Dalloz-Sirey, jan.-mar. 1995, n. 1, pp. 207-212.

Le nouveau code civil. Revue Trimestrielle de Droit Civil. Paris Dalloz-Sirey, out.-dez. 1993, n. 4, pp.911-920.

L'influence de la doctrine française sur le droit civil québécois. Le rapprochement et l'éloignement de deux continents. Revue Internationale de Droit Comparé. Paris : Société de Législation Comparée, abr.-jun. 1992, n. 2, pp. 381-408

MARQUIS, Louis. L'influence du modèle juridique français sur le droit québécois de l'arbitrage conventionnel. Revue Internationale de Droit Comparé. Paris Société de Législation Comparée, jul.-set. 1993, n. 3, pp. 577-618.

VACHON, Patrice. Une vue d'ensemble du nouveau code civil du Québec. Le Réseau Juridique du Québec. Internet : 2000. (http:/ /www.avocat.qc.ca/public/iiccqvachon.htm)
3. Obras específicas sobre o novo Código Civil brasileiro

COUTO E SILVA, Clóvis do. O direito civil brasileiro em perspectiva histórica e visão de futuro. In: $O$ direito privado brasileiro na visão de Clóvis do Couto e Silva. Org. por Vera Maria Jacob de Fradera. Porto Alegre: Livraria do Advogado, 1997, pp. 11-31.

MARTINS-COSTA, Judith. O direito privado como um "sistema em construção". As cláusulas gerais no Projeto do Código Civil brasileiro. Revista de Informação Legislativa, vol. 139. Brasília : Senado Federal, 1998, pp. 5-22.

MARTINS-COSTA,Judith, BRANCO, Gerson Luiz Carlos.Diretrizesteóricas do novo Código Civil brasileiro. SãoPaulo:Saraiva, 2002.

MOREIRA ALVES, José Carlos. A Parte Geral do Projeto do Código Civil brasileiro. São Paulo : Saraiva, 1986.

REALE, Miguel. O Projeto do novo Código Civil. 2. ed. São Paulo : Saraiva, 1999.

SILVA, Eduardo Silva da. Projeto do Código Civil: a importância das cláusulas gerais na regulação do direito pessoal e patrimonial de família. Revista da Faculdade de Direito da UFRGS, vol. 15. Porto Alegre : Síntese, 1998, pp. 55-73.

\section{Obras de caráter auxiliar}

BRACHET, Bernard. La crise du fédéralisme canadien et le problème québécois. Revue du Droit Public et de la Science Politique en France et à l'étranger. Paris : Librairie Générale de Droit e de Jurisprudence, mar.abr. 1972, n. 2,pp. 303-324.

CORTIANO JUNIOR, Eroulths. Alguns apontamentos sobre os chamados direitos da personalidade. In: FACHIN, Luiz Edson (coord.), et al. Repensando fundamentos do direito civil brasileiro contemporâneo. Rio de Janeiro : Renovar, 1998, pp. 31-56.
COUTO E SILVA, Almiro do. Romanismo e germanismo no Código Civil brasileiro. Revista da Faculdade de Direito da UFRGS, vol. 13/14.Porto Alegre: Síntese, 1997, pp.7-27.

CUNHA, Alexandre dos Santos. Dignidade da pessoa humana: conceito fundamental do direito civil. In: MARTINS-COSTA, Judith (org.), et al. A reconstrução do direito privado. São Paulo : Revista dos Tribunais, 2002,pp. 230-264.

DAVID, René. O direito inglês. Trad. por Eduardo Brandão. São Paulo : Martins Fontes, 1997.

DIDIER, Emmanuel. La common law en français: étude juridique et linguistique de la common law en français au Canada. Revue Internationale de Droit Comparé. Paris : Société de Législation Comparée, jan.-mar. 1991, n. 1, pp. 7-56.

GLENN, H. Patrick. La civilisation de la common law. Revue Internationale de Droit Comparé. Paris : Société de Législation Comparée, jul.-set. 1993, n. 3, pp. 559-575.

GOMES, Orlando.Direitos reais. 12. ed. Rio de Janeiro : Forense, 1997

LUDWIG, Marcos de Campos. O direito ao livre desenvolvimento da personalidade na Alemanha e possibilidades de sua aplicação no direito privado brasileiro. In MARTINS-COSTA, Judith (org.), et al. A reconstrução do direito privado. São Paulo : Revista dos Tribunais, 2002, pp. 265 305 .

MARTINS-COSTA, Judith. O sistema na codificação civil brasileira: de Leibniz a Teixeira de Freitas. Revista da Faculdade de Direito da UFRGS, vol. 17. Porto Alegre : Síntese, 1999, pp. 189-204.
MAZEN, Noël Jean. Le juge civil québécois (approche comparative d'un système de droit mixte). Revue Internationale de Droit Comparé. Paris : Société de Législation Comparée, abr.-jun. 1982, n. 2, pp. 375-404.

MIRANDA, Jorge. Manual de direito constitucional. 4. ed. Coimbra: Coimbra, 1990, t. I.

MOTA PINTO, Paulo. Notas sobre o direito ao livre desenvolvimento da personalidade $\mathrm{e}$ os direitos de personalidade no Direito português. In: SARLET, Ingo Wolfgang (org.), et al. A Constituição concretizada. Construindo pontes com o público e o privado. Porto Alegre : Livraria do Advogado, 2000, pp. 61-83.

PHILIP, Christian. Le Québec et le "repatriement" de la Constitucion canadienne. Revue du Droit Public et de la Science Politique en France et à l'étranger. Paris : Librairie Générale de Droit e de Jurisprudence, nov.-dez. 1982, n. 6, pp. 1567-1600.

PONTES DE MIRANDA, Francisco Cavalcanti. Fontes e evolução do direito civil brasileiro. 2. ed. Rio de Janeiro : Forense, 1981.

RABELLO, Alfredo Mordechai. Montesquieu et la codification du droit privé (le Code Napoléon). Revue Internationale de Droit Comparé. Paris : Société de Législation Comparée, jan.-mar. 2000, n. 1, pp. 147-156.

THUNIS, Xavier, MENSBRUGGHE, François van der. À la recherche de la possession en droit anglais. Revue Internationale de Droit Comparé. Paris : Société de Législation Comparée, jan.-mar. 2000, n. 1, pp. $77-100$.

TIMM, Luciano B. Da prestação de serviços. Porto Alegre : Síntese, 1998. 